\title{
The impact of internal control on management expenses
}

\author{
Yuanfeng Xue \\ Nanjing University of Science and Technology, Nanjing, China
}

\begin{abstract}
Administrative expenses affect the profitability of enterprises, an thorough internal control can save administrative expenses or reduce unnecessary administrative expenses. Taking listed manufacturing companies as samples, this paper studies the relationship between the quality of internal control and management costs with empirical methods, aimed at providing useful references for listed manufacturing companies in China to improve the utilization efficiency of management costs and internal control. Study shows that: (1) the improvement of internal control quality helps to reduce the proportion of overall management costs significantly, (2) the effective internal control can also significantly inhibit the proportion of pay, office, travel, business entertainment and commission in the administration expense, (3) improving the quality of internal control can't significantly reduce the proportion of $r \& d$.
\end{abstract}

Keywords: Internal control; Administrative expense; manufacturing industry; Listed company

\section{Introduction}

In recent years, domestic and foreign companies have frequently experienced business failures due to imperfect internal control, such as the bankruptcy of WorldCom in the United States and the failure of China Asia Corporation, all due to internal management failures, fraudulent financial statements, etc. Major economic losses and even bankruptcy and reorganization caused by reasons. It is precisely because of the emergence of many internal control failures that the relevant regulatory agencies in the United Kingdom and the United States and other Western countries have successively issued laws and regulations and issued internal control reports, trying to regulate the internal control system of enterprises through these, which has attracted the attention of enterprises. Influenced by Western internal control theories and forced by my country's economic development situation, my country has introduced the "Basic Standards for Enterprise Internal Control" called the "Chinese version of the SOX Act" and the subsequent "Supporting Guidelines", which are generally for Chinese enterprises. The implementation of a sound internal control system provides a unified basic framework.

With the rapid economic development and the continuous expansion of the scale of enterprises, the management functions of the corporate administrative departments are also continuously extended and expanded, and various expenses incurred have also increased rapidly. As an important component of enterprise period expenses, management expenses have attracted more and more attention from modern enterprises. How to control management expenses has also become the key task of enterprise cost and expense control. The reduction of management costs has also become the most important means for corporate shareholders and management to achieve corporate goals, which is of great significance for improving corporate profits and achieving corporate economic benefits.

\section{Literature review}

As one of the effective ways to improve the modern company system, internal control plays an important role in improving the operation and management level of listed companies and avoiding risks (Hou Baoliang, 2014). The job fraud case of Societe Generale in 2008 has sounded the alarm for all companies. The characteristics of job fraud, such as high incidence, high harm, various forms, and complex causes, require all enterprises to actively respond. This case shows that effective internal control is the key to preventing job fraud ( $\mathrm{He} \mathrm{Yu,} \mathrm{2009).} \mathrm{The} \mathrm{loss} \mathrm{of} \mathrm{this} \mathrm{kind} \mathrm{of} \mathrm{workplace} \mathrm{fraud} \mathrm{to}$ the company is unpredictable, and it will undoubtedly bring about a sharp increase in management costs. 
The research on internal control quality and employee compensation mainly focuses on executive compensation. Companies with internal control defects tend to have low quality accounting information. Low accounting information not only misleads managers' management decisions (Feng Mei, 2009), but also makes it difficult for external investors to effectively supervise managers' behavior. Advantageous behavior may be more serious (Kanodia C, 1998). There is a significant positive correlation between the quality of internal control and executive compensation. This shows that with the gradual establishment and improvement of my country's internal control standard system, companies have begun to consider internal control, a non-risk control based on risk control, when determining executive compensation. Financial factors are taken into consideration (Chi Guohua, Guo Jingjing. 2015). What's more interesting is that the higher the quality of internal control, the more sensitive the performance of management compensation. In other words, management has the motivation to increase its salary level when performance increases, but rarely reduces it when performance declines. Effective internal control can suppress this selective salary change (Lu Rui et al., 2011).

China is a relational society, and the establishment of business entertainment fees is conducive to cooperation with partners and government officials. But business entertainment may also produce a kind of agency cost that is opposite to production and worthless output (Hart, 2001). Chen Donghua et al. (2010) pointed out that if the on-the-job consumption, including business entertainment expenses, is not well controlled, the agent may overspend in pursuit of private income, which will lead to high agency costs. Regarding the two different views on business entertainment, Wan Hualin (2007) proposed from the perspective of internal control that the effectiveness of internal control determines the equilibrium point between the agency view and the efficiency view of on-the-job consumption. The implementation of internal control can significantly inhibit the on-the-job consumption of the company's executives, while improving the company's performance (Dou Xiangsheng, Wang Zaifeng, Zhang Ruixiong, 2017), and the lack of feasibility and restraint effectiveness of the internal control system itself can lead to misuse of business entertainment ( $\mathrm{Li}$ Jingping, Xue Yiyi, 2010). Regarding the impact of internal control on business expenses of enterprises, some scholars have put forward supplementary studies on the nature of the enterprise and the power of executives. High-quality internal control significantly reduces the extent of excessive in-service consumption of listed companies, and the inhibitory effect of internal control on excessive in-service consumption in state-owned listed companies is more obvious (Mou Shaohong, Li Qihang, Chen Hanwen, 2016). The research shows that internal control is negatively related to the hidden corruption of executives. As the internal management mechanism of state-owned enterprises, internal control can supervise the hidden corruption of executives (Fu Chao.2018). In addition, existing empirical studies have also found that the greater the power of management, the more serious they use their extravagant on-the-job consumption to implement power rent-seeking (Lu Rui et al., 2008).

The impact of internal control on R\&D scholars at home and abroad hold two different views. Some scholars believe that internal control will have a positive effect on corporate R\&D investment. Simons (1995) was the first to put forward the "internal control promotion theory", and believed that sound internal control has "pioneering and innovative thinking". The reason is that the introduction of an internal control system can clearly position the innovation investment goals and the planning structure process, thereby having a positive impact on innovation investment (Verona, 1999). Internal control takes the form of a system to suppress the short-sighted behavior of executives in investment decision-making through risk assessment and executive incentive systems (Li Wanfu et al., 2011).

Some scholars believe that internal control will have a negative effect on the company's R\&D investment. Kaplan and Norton (1996) first proposed the "internal control paradox" that internal control may inhibit innovation investment. They believe that innovation is a process that requires constant trial and error and is full of uncertainty. If the company places too much emphasis on control, formulate formal control points. , Personnel appraisal and evaluation standards may cause the entire organization to fall into rigid conformity and unwillingness to undertake risky innovative activities. $\mathrm{Wu}$ Ning et al. (2015) There is a significant negative correlation between internal control and 
corporate risk-taking, and this relationship is more sensitive in non-state-owned enterprises, that is, internal control inhibits entrepreneurs' adventurous spirit and sense of risk-taking and hinders Innovation investment.

At present, the impact of internal control quality on intermediary fees is mainly focused on audit fees. Different scholars hold different opinions on whether internal control can significantly reduce audit fees. Some scholars support this and believe that there is a significant negative correlation between the quality of internal control and audit fees (Quan Xiaofeng and Xu Xingmei, 2017). Some scholars believe that there is a negative correlation between the quality of internal control and audit fees, but it is not significant (Song Yinghui and Chen Yanrong, 2013). The more mainstream view is that effective internal control can reduce audit costs. The reason is that on the one hand, the auditor will evaluate and test the internal control of the audit unit when determining the audit input. For companies with high internal control quality, audit investment can be reduced. On the other hand, companies with high internal control quality face The risk is smaller, which will also reduce the risk premium required by the auditor. Taking these two aspects into account, the improvement of the quality of internal control can reduce the company's audit fees.

Audit fees for companies with internal control deficiencies are higher (Raghumanda and Rama, 2006), and the higher the degree of deficiencies, the higher the audit fees (Hoitash and Bedard, 2008). In addition, internal control and external audit have a mutual substitution effect, that is, there is a significant positive correlation between audit fees and major deficiencies in internal control (Xiao Chengmin and Li Rong. 2012). After further discussing the mechanism according to the nature of different property rights, it is found that the audit fees charged by certified public accountants for companies with major internal control defects are higher, and compared with non-state-owned enterprises, this phenomenon is more significant in state-owned enterprises (Li Yuedong, Zhang Dong and Liu Weiwei, 2014). Some scholars have put forward supplementary opinions from the perspective of management power. Deng Wentao et al. (2018) believe that the influence of management power and internal control on audit fees is mutually restrictive. Management power will weaken the negative correlation between internal control and audit fees. Internal control will weaken the positive correlation between management power and audit fees.

To sum up, the previous literature has rarely studied the influence of internal control on the overall management cost, and some researched the sales cost and management cost as a whole. This study has done the impact of internal control on the overall management cost. Secondly, in the past, the impact of internal control on remuneration and intermediary fees was mainly concentrated on executive compensation and audit fees. This study took the employee compensation and intermediary fees in the overall management expenses as the research object, and broadened the relevant remuneration, intermediary fees and internal control. Relationship research. In addition, there are few empirical studies on office expenses, travel expenses, and business entertainment expenses, and this study has supplemented them.

\section{Theoretical analysis and research hypothesis}

Modern enterprise theory believes that an enterprise is essentially a combination of a series of incomplete contracts. Due to the incompleteness of the corporate contract, the managers of the company often pursue the maximization of personal interests rather than the maximization of shareholders' interests, which leads to the principal-agent problem (Berle and Means, 1932). It is generally believed that the greater the power of the management, the more serious the corruption; the better the quality of internal control, the less the corruption, and internal control can inhibit the power of the management to suppress the corruption caused by the abuse of power by the management (Zhou Meihua, Lin Bin, Lin Dongjie, 2016) .

Since corporate managers often pursue the maximization of their own interests rather than the maximization of corporate profits, this leads to the problem of principal-agent. In other words, if the wealth of an enterprise is regarded as a resource, business managers have a tendency to allocate more 
resources into their pockets. The internal control plays a vital role in ensuring the company's good operation, and it can supervise and restrict the company's interior (Lu Yuanyuan. 2018). Effective internal control can constrain the self-interested behavior of management through the constraints of systems and procedures, make its goals consistent with corporate profits, and reduce corporate invalid management expenses. Based on this, we propose the following hypotheses:

H1: Under the circumstance that other conditions remain unchanged, the quality of internal control is significantly negatively correlated with the proportion of management expenses.

The theory of management power believes that management has the motivation to use power to seek rent and exert an important influence on its own compensation arrangements, that is, management has a subjective tendency to increase salaries for itself. Effective internal control can rely on the remuneration committee, the board of supervisors and other institutions to supervise and control the salary and benefits of the management, prevent the management from increasing their own wages and welfare standards at will, and thereby inhibit the increase of ineffective employee compensation. In summary, this research proposes the following hypotheses:

H2: Under the circumstance that other conditions remain unchanged, there is a significant negative correlation between the quality of internal control and the proportion of employee compensation.

When using office supplies, the management may order too many stationery or newspapers and magazines for convenience, or may print too many materials that do not need to be printed...The management's randomness in ordering and using office supplies will not only cause ordering costs The increase in the cost of office supplies will also result in waste of office supplies, which in turn will increase the company's office expenses. Effective internal control can regulate the procurement of office supplies through the system, reduce ineffective procurement, and can stipulate the allowable share of each department or position, and deal with the excess share, thereby reducing the expenditure of invalid office expenses. Therefore, this study makes the following assumptions:

H3: Under the circumstance that other conditions remain unchanged, there is a significant negative correlation between the quality of internal control and the proportion of office expenses.

Travel expenses are an important part of the non-monetary private income of executives. When they go out and work, management has a tendency to stay in hotels with better conditions and choose more comfortable means of transportation, and this tendency will increase travel expenses. Internal control can restrict management's expenses for excessive travel expenses such as staying in high-end hotels at will by stipulating the benefits that people in specific positions can enjoy when they travel, and requiring approval or non-reimbursement of benefits that exceed the standard. In addition, effective internal control can plan business trips through work plans and other methods to obtain more favorable prices and reduce the arbitrariness of business trips. Therefore, this research proposes the following hypotheses:

H4: Under the circumstance that other conditions remain unchanged, there is a significant negative correlation between the quality of internal control and the proportion of travel expenses.

The agency problem between managers and shareholders is mainly manifested in the fact that managers are more inclined to expand the scale of the enterprise or make excessive investment in order to build a corporate empire with themselves as the core. The future competitiveness that may be brought about by $R \& D$ investment is to build the enterprise. An important driving force for the empire. Sound internal control clarifies the responsibilities of various departments and employees through organization, planning, division of labor, authorization, independent responsibility system, incompatible position approval, etc., so as to realize the standardization and institutionalization of the innovation investment process, and reduce the agency cost of the enterprise innovation investment operation level And the degree of information asymmetry (Fang Hongxing and Jin Yuna, 2013). Moreover, whether R\&D investment can bring future benefits to the company and the size of future benefits are highly uncertain. Good internal control can conduct risk assessment and risk management on the company's R\&D investment and reduce excessive risk of R\&D investment. Based on this, this research proposes the following hypotheses: 
H5: Under the circumstance that other conditions remain unchanged, the quality of internal control is significantly negatively correlated with the proportion of $R \& D$ expenditure.

The resources that the management can obtain from the enterprise are not limited to the salary itself. Although the business entertainment is not given to the manager in the form of direct salary, it is essentially a resource for the manager. Appropriate business entertainment can promote the development of corporate business and bring higher returns to shareholders, but excessive business entertainment will encroach on corporate resources and cause damage to shareholders' interests. Management as a rational economic man The form of public money eating and drinking increases the tendency of one to obtain resources, which will cause the principal-agent problem. Effective internal control can combine the management's business hospitality expenditure standard with performance, positions and other factors in the form of a system, and formulate reasonable hospitality standards based on the principles of cost-benefit and other principles, thereby restricting the management's arbitrary hospitality behavior effect. Based on this, this research proposes the following hypotheses:

H6: Under the circumstance that other conditions remain unchanged, there is a significant negative correlation between the quality of internal control and the proportion of business entertainment.

Effective specialized division of labor plays an important role in promoting the development of enterprises. This also makes enterprise intermediary agency fees become an important part of enterprise management expenses, but excessively high intermediary fees will also burden the enterprise management expenses. The management is obliged to work hard to reduce the intermediary costs for the enterprise when accepting the entrustment of shareholders. However, due to the entrusted agency problem, the management cannot always work in the manner expected by the shareholders. On the one hand, when the management chooses intermediary agencies, there may be a situation in which they are partial to their relatives and friends or even collude inside and outside, which may cause an increase in intermediary fees or a decrease in the quality of intermediary services. On the other hand, due to the management's negligence in management, the increase in intermediary services required by the company has led to an increase in intermediary costs, such as an increase in litigation consulting costs due to excessive product quality issues. Effective internal control can limit the personalization tendency of managers when choosing intermediary agencies through the standardization of procedures, and can also monitor and control the selection of intermediary agencies beforehand and afterwards through procedures, making the selection of intermediary agencies more transparent and more transparent. Conducive to the maximization of corporate target profits. Moreover, internal control is also conducive to the standardization of business operations, which will reduce unnecessary intermediary services caused by management errors in management, which can also reduce intermediary costs. Based on this, this research proposes the following hypotheses:

H7: Under the circumstance that other conditions remain unchanged, the quality of internal control is significantly negatively correlated with the proportion of intermediary costs.

\section{4. research design}

\subsection{Sample selection and data sources}

This study uses the 1896 listed manufacturing companies in the "Industry Classification Results of Listed Companies in the 4th Quarter of 2016" issued by the China Securities Regulatory Commission as a sample to examine the influence of internal control quality on the proportion of management expenses and the proportions of various components of management expenses. The data on the proportion of management expenses, the proportion of each component of management expenses and other control variables are collected from the Cathay Pacific database and the RES database. The internal control quality data is collected from the Dibo internal control and risk management database. The time for data collection is September 1, 2018 to October 15, 2018. In addition, we excluded ST companies and companies with abnormal internal control quality indexes, and finally selected the remaining 1,634 listed manufacturing companies as the research object. The processing software of this research is EVIEWS7 software. 
Table 1. Sample size

\begin{tabular}{|c|c|c|c|c|c|c|c|}
\hline Type & $\begin{array}{c}\text { Total } \\
\text { sampl } \\
\mathrm{e}\end{array}$ & $\begin{array}{c}\text { Employee } \\
\text { compensatio } \\
\mathrm{n}\end{array}$ & $\begin{array}{c}\text { Office } \\
\text { expense } \\
\mathrm{s}\end{array}$ & $\begin{array}{c}\text { Travel } \\
\text { expense } \\
\mathrm{s}\end{array}$ & $\begin{array}{c}\text { R\&D } \\
\text { expense } \\
\mathrm{s}\end{array}$ & $\begin{array}{c}\text { Business } \\
\text { entertainmen } \\
\text { t expenses }\end{array}$ & $\begin{array}{c}\text { Intermediar } \\
\text { y expenses }\end{array}$ \\
\hline $\begin{array}{c}\text { Numbe } \\
\text { r of } \\
\text { samples }\end{array}$ & 1634 & 1573 & 1246 & 1248 & 1384 & 1191 & 1115 \\
\hline
\end{tabular}

\subsection{Variable definition and model construction}

\subsubsection{Variable definition}

The proportion of management expenses, the proportion of employee compensation, the proportion of office expenses, the proportion of travel expenses, the proportion of R\&D expenditure, the proportion of business entertainment, the proportion of intermediary expenses: all are measured by the proportion of various expenses to the total operating income of the year, taking into account that cost and income are composed The two pillars of profit are in line with the logic of companies wishing to maximize profits and have practical significance;

Internal control quality: Drawing lessons from previous studies (Fang Hongxing et al., 2016; Lu Yuanyuan. 2018), this article uses Dibo's internal control quality index as the standard to measure the quality of internal control. The larger the index, the better the quality of internal control;

Asset scale: At present, most academic circles use the natural logarithm of total assets as the asset scale, and this research also uses this method;

Enterprise nature: dummy variable, 1 if the company is a state-owned enterprise, 0 otherwise;

Ownership concentration: The shareholding ratio of the previous ten largest shareholders is used as a measure of equity concentration.

\subsubsection{Model building}

This study constructs the following model to test the influence of internal control quality on the proportion of management expenses and the proportion of each component of management expenses:

$\mathrm{Y}_{\mathrm{i}}=\beta \mathrm{i}_{0}+\beta_{\mathrm{i} 1} * \mathrm{IC}_{\mathrm{i} 1}+\beta_{\mathrm{i} 2} * \mathrm{Size}_{\mathrm{i} 2}+\beta_{\mathrm{i} 3} * \mathrm{SOE}_{\mathrm{i} 3}+\beta_{\mathrm{i} 4} * \mathrm{H} 10_{\mathrm{i} 4}+\varepsilon_{\mathrm{i}}$ (where $\mathrm{i}$ is $1-7$ )

Among them, $\mathrm{Yi}$ is the explained variables, that is, the proportion of management expenses and the proportion of each component of management expenses. The explanatory variable is internal control quality $\mathrm{Ic}_{\mathrm{i}}$, and the control variables are asset scale, enterprise nature, and equity concentration. See Table 2 for the definition of all variables.

Table 2. Variable definition table

\begin{tabular}{c|c|c|c}
\hline Variable type & $\begin{array}{c}\text { Variable } \\
\text { name }\end{array}$ & Variable definition & Measurement \\
\hline \multirow{5}{*}{$\begin{array}{c}\text { Explained } \\
\text { variable }\end{array}$} & Management & $\begin{array}{c}\text { Management expense } \\
\text { proportion }\end{array}$ & $\begin{array}{c}\text { Management expense/total } \\
\text { operating income }\end{array}$ \\
\cline { 2 - 4 } & Pay & $\begin{array}{c}\text { Employee Compensation } \\
\text { Ratio }\end{array}$ & $\begin{array}{c}\text { Employee Compensation/Total } \\
\text { Operating Income }\end{array}$ \\
\cline { 2 - 4 } & Travel & $\begin{array}{c}\text { Proportion of Office } \\
\text { Expenses }\end{array}$ & $\begin{array}{c}\text { Expenses Office Expenses/Total } \\
\text { Operating Income }\end{array}$ \\
\cline { 2 - 4 } & R\&D & $\begin{array}{c}\text { Expenses Ratio } \\
\text { R\&D expenditure ratio }\end{array}$ & $\begin{array}{c}\text { Travel Expenses/Total Operating } \\
\text { Income }\end{array}$ \\
\cline { 2 - 4 } & Entertainment & $\begin{array}{c}\text { Business Entertainment } \\
\text { Expenses Proportion } \\
\text { income }\end{array}$ & $\begin{array}{c}\text { Business Entertainment } \\
\text { Expenses/Total Operating Income }\end{array}$ \\
\cline { 2 - 4 } & Agent & $\begin{array}{c}\text { Intermediary Fee } \\
\text { Proportion }\end{array}$ & $\begin{array}{c}\text { Intermediary Fee/Total Operating } \\
\text { Income }\end{array}$ \\
\hline
\end{tabular}




\begin{tabular}{c|c|c|c}
\hline $\begin{array}{c}\text { Explanatory } \\
\text { variable }\end{array}$ & lc & Internal control quality & Dib internal control quality index \\
\hline \multirow{2}{*}{$\begin{array}{c}\text { Control } \\
\text { variable }\end{array}$} & Size & Company size & Natural logarithm of total assets \\
\cline { 2 - 4 } & SOE & Enterprise Nature & $\begin{array}{c}\text { Whether it is a state-owned } \\
\text { enterprise, it is 1; otherwise, it is 0 }\end{array}$ \\
\cline { 2 - 4 } & H10 & Stockholding & $\begin{array}{c}\text { concentration ratio of the top ten } \\
\text { shareholders }\end{array}$ \\
\hline
\end{tabular}

\section{Empirical test and analysis}

\subsection{Descriptive statistics}

Table 3. Descriptive Statistics

\begin{tabular}{c|c|c|c|c|c}
\hline Variable & Mean & Median & Maximum & Maximum & Standard Deviation \\
\hline Management & 0.1123 & 0.0962 & 1.4952 & 0.0038 & 0.0893 \\
\hline IC & 654.5061 & 662.3900 & 859.5200 & 206.6600 & 69.2751 \\
\hline Size & 22.1286 & 22.0234 & 28.5052 & 17.8061 & 1.1760 \\
\hline SOE & 0.276702 & 0 & 1 & 0 & 0.4475 \\
\hline H10 & 57.6529 & 58.4500 & 100 & 14.6700 & 14.1506 \\
\hline
\end{tabular}

Table 3 uses the structure of descriptive statistics based on the proportion of management expenses. It can be seen that in the sample data, the average value of the proportion of management expenses is 0.111560 . The median of management expenses is 0.096207 , which are all around 0.1 , which shows that the average value of management expenses in total operating income is representative. The maximum proportion of administrative expenses is 1.495171 , and the proportion of administrative expenses to total operating income is obviously abnormal. This is because the total operating income of the corresponding Huazi Industrial in recent years is far less than the operating cost, and the main way for enterprises to realize profits is investment income. The minimum proportion of administrative expenses is 0.003773, and the corresponding company is Qingdao Haier. The company's internal control quality index is also the largest, 859.52. This is consistent with the expectation of the negative correlation between the expected internal control quality and the proportion of excess management expenses in this study.

The minimum value of the internal control quality index is 206.66, and the proportion of excess management expenses of the corresponding company Kairuide is also relatively large, reaching 0.553184 , which is much higher than the average level. The maximum value of the internal control quality index is 859.52 , as explained in the previous paragraph.

The total assets of the sample ranged from RMB 17.8061 to RMB 28.5052, with the average and median values being around 22 .

The median and average share of the top ten shareholders are both around 58\%, indicating that the average share of the top ten shareholders should be around $58 \%$.

\subsection{Correlation analysis}

Table 4. Pearson correlation coefficient matrix

\begin{tabular}{c|c|c|c|c|c}
\hline & Management & IC & Size & SOE & H10 \\
\hline Management & 1 & & & & \\
\hline IC & $-0.184^{* * *}$ & 1 & & & \\
\hline Size & $-0.300^{* * *}$ & $0.159^{* * *}$ & 1 & & \\
\hline SOE & $-0.108^{* * *}$ & 0.037 & $0.374^{* * *}$ & 1 & \\
\hline
\end{tabular}




\begin{tabular}{|l|l|}
\hline $0.067^{* * *}$ & 1 \\
\hline
\end{tabular}

Note: * means significant at the $10 \%$ level, $* *$ means significant at the $5 \%$ level, and $* * *$ means significant at the $1 \%$ level.

Table 4 is the Pearson correlation coefficient matrix of the proportion of management expenses. It can be seen from the table that the coefficients of Manangement and IC are significantly negatively correlated at the level of $1 \%$. Small, enterprises can get more profits.

Table 5. Pearson correlation coefficient matrix of the proportion of employee compensation

\begin{tabular}{c|c|c|c|c|c}
\hline & Pay & IC & Size & SOE & H10 \\
\hline Pay & 1 & & & & \\
\hline IC & $-0.067^{* * *}$ & 1 & & & \\
\hline Size & $-0.117^{* * *}$ & $0.144^{* * *}$ & 1 & & \\
\hline SOE & -0.041 & 0.022 & $0.342^{* * * *}$ & 1 & \\
\hline H10 & -0.022 & $0.162^{* * *}$ & $0.087^{* * *}$ & $0.074^{* * *}$ & 1 \\
\hline
\end{tabular}

Note: * means significant at the $10 \%$ level, ** means significant at the $5 \%$ level, and $* * *$ means significant at the $1 \%$ level.

Table 5 is the Pearson correlation coefficient matrix of the proportion of employee compensation. It can be seen from the table that the coefficients of Pay and IC are significantly negatively correlated at the level of $1 \%$. The proportion of revenue will decline, which will ultimately help companies achieve more profits.

Table 6 is the Pearson correlation coefficient matrix of the proportion of office expenses. It can be seen from the table that the coefficients of Pay and IC are significantly negatively correlated at the level of $1 \%$. This shows that the office expenses of manufacturing enterprises with better internal control quality account for the total operating income. The smaller the proportion, which helps the realization of the goal of maximizing corporate profits.

Table 6. Pearson correlation coefficient matrix of the proportion of office expenses

\begin{tabular}{c|c|c|c|c|c}
\hline & Office & IC & Size & SOE & H10 \\
\hline Office & 1 & & & & \\
\hline IC & $-0.129^{* * *}$ & 1 & & & \\
\hline Size & $-0.187^{* * *}$ & $0.145^{\text {*** }}$ & 1 & & \\
\hline SOE & $-0.152^{* * *}$ & 0.005 & $0.341^{* * *}$ & 1 & \\
\hline H10 & 0.006 & $0.166^{* * *}$ & 0.141 & $-0.099^{* * *}$ & 1 \\
\hline
\end{tabular}

Note: * means significant at the $10 \%$ level, ** means significant at the $5 \%$ level, and $* * *$ means significant at the $1 \%$ level.

Table 7. Pearson correlation coefficient matrix of the proportion of travel expenses

\begin{tabular}{c|c|c|c|c|c}
\hline & Travel & IC & Size & SOE & H10 \\
\hline Travel & 1 & & & & \\
\hline IC & $-0.112^{* * *}$ & 1 & & & \\
\hline Size & $-0.214^{* * *}$ & $0.123^{* * *}$ & 1 & & \\
\hline SOE & $-0.141^{* * *}$ & 0.016 & $0.308^{* * *}$ & 1 & \\
\hline
\end{tabular}


Note: * means significant at the $10 \%$ level, ** means significant at the $5 \%$ level, and $* * *$ means significant at the $1 \%$ level.

Table 7 is the Pearson correlation coefficient matrix of the proportion of travel expenses. It can be seen from the table that the coefficients of Travel and IC are significantly negatively correlated at the level of $1 \%$. This shows that if the quality of the company's internal control is better, then the company's travel expenses account for the total operating income. The lower the proportion.

Table 8. Pearson Correlation Coefficient Matrix of R\&D Expenditure Proportion

\begin{tabular}{c|c|c|c|c|c}
\hline & R\&D & IC & Size & SOE & H10 \\
\hline R\&D & 1 & & & & \\
\hline IC & -0.047 & 1 & & & \\
\hline Size & $-0.195^{* * *}$ & $0.125^{* * *}$ & 1 & & \\
\hline SOE & $-0.063^{* * *}$ & 0.021 & $0.354^{* * *}$ & 1 & \\
\hline H10 & -0.031 & $0.147^{* * *}$ & $0.055^{* *}$ & $-0.102^{* * *}$ & 1 \\
\hline
\end{tabular}

Note: * means significant at the $10 \%$ level, $* *$ means significant at the $5 \%$ level, and $* * *$ means significant at the $1 \%$ level.

Table 8 is the Pearson correlation coefficient matrix of the proportion of management expenses. It can be seen from the table that the coefficients of R\&D and IC are not significant. This shows that companies with high control quality have not reduced the proportion of $R \& D$ expenditure in operating income. This may be due to R\&D. Expenses are good for improving the company's future profitability.

Table 9 is the Pearson correlation coefficient matrix of the proportion of business entertainment expenses. It can be seen from the table that the coefficients of Entertainment and IC are significantly negatively correlated at the $1 \%$ level. This shows that the better the quality of internal control, the enterprises tend to have lower business entertainment expenses. The proportion of total operating income.

Table 9. Pearson correlation coefficient matrix of of business entertainment expenses

\begin{tabular}{c|c|c|c|c|c}
\hline & Entertainment & IC & Size & SOE & H10 \\
\hline Entertainment & 1 & & & & \\
\hline IC & $-0.106 * * *$ & 1 & & & \\
\hline Size & $-0.150 * * *$ & $0.131 * * *$ & 1 & & \\
\hline SOE & $-0.091 * * *$ & 0.003 & $0.324 * * *$ & 1 & \\
\hline H10 & 0.004 & $0.159 * * *$ & 0.048 & $-0.119 * * *$ & 1 \\
\hline
\end{tabular}

Note: * means significant at the $10 \%$ level, ** means significant at the $5 \%$ level, and $* * *$ means significant at the $1 \%$ level.

Table 10. Pearson Correlation Coefficient Matrix of Intermediary Fee Proportion

\begin{tabular}{c|c|c|c|c|c}
\hline & Agent & IC & Size & SOE & H10 \\
\hline Agent & 1 & & & & \\
\hline IC & $-0.229 * * *$ & 1 & & & \\
\hline Size & $-0.201 * * *$ & $0.121 * * *$ & 1 & & \\
\hline SOE & $-0.098 * * *$ & 0.014 & $0.291 * * *$ & 1 & \\
\hline H10 & 0.047 & $0.152 * * *$ & $0.091 * * *$ & $-0.094 * * *$ & 1 \\
\hline
\end{tabular}


Note: * means significant at the $10 \%$ level, ** means significant at the $5 \%$ level, and $* * *$ means significant at the $1 \%$ level.

Table 10 is the Pearson correlation coefficient matrix of the proportion of intermediary fees. It can be seen from the table that the coefficients of Agent and IC are significantly negatively correlated at the level of $1 \%$. The lower the proportion of operating income will be, which will ultimately help enterprises achieve more profits.

\subsection{Results and analysis of multiple linear regression}

Table 11. Return of administrative expenses

\begin{tabular}{c|c|c|c|c}
\hline Variable & Coefficient & Std. Error & t-Statistic & Prob. \\
\hline Intercept & $0.696222^{* * *}$ & 0.044166 & 15.76369 & 0.0000 \\
\hline IC & $-0.000171^{* * *}$ & $3.12 \mathrm{E}-05$ & -5.476076 & 0.0000 \\
\hline Size & $-0.020980^{* * *}$ & 0.001953 & -10.74442 & 0.0000 \\
\hline SOE & -0.001832 & 0.005057 & -0.362171 & 0.7173 \\
\hline H10 & -0.000141 & 0.000152 & -0.926761 & 0.3542 \\
\hline $\mathrm{R}^{2}$ & \multicolumn{5}{|c}{0.110} \\
\hline F value & \multicolumn{5}{|c}{$1634^{* * *}$} \\
\hline Sample size & \multicolumn{5}{|c}{} \\
\hline
\end{tabular}

Note: * means significant at the $10 \%$ level, ** means significant at the $5 \%$ level, and *** means significant at the $1 \%$ level.

Table 11 is the regression result of the model based on the assumption H1. From the table, we can see that in the multiple linear regression, the coefficient of internal control quality and (management expense/total operating income) is negative, and the result is obviously significant. In other words, the quality of internal control and the proportion of management expenses show an expected significant negative correlation, which shows that the improvement of the quality of internal control can effectively suppress the proportion of management expenses in total operating income.

Table 12 is the regression results of the model based on the assumption of H2. From the table, we can see that in the multiple linear regression, the coefficient of internal control quality and (employee compensation/total operating income) is negative, and the result is significant at the 5\% level. In other words, the quality of internal control and the proportion of employee compensation show the expected significant negative correlation, which shows that the improvement of internal control quality can reduce the proportion of employee compensation, but the significance is slightly reduced.

Table 12. Return of employee compensation

\begin{tabular}{c|c|c|c|c}
\hline Variable & Coefficient & Std. Error & t-Statistic & Prob. \\
\hline Intercept & $0.037102^{* * *}$ & 0.046309 & 8.011834 & 0.0000 \\
\hline IC & $-6.25 \mathrm{E}-05^{* *}$ & $3.23 \mathrm{E}-05$ & -1.934872 & 0.0532 \\
\hline Size & $-0.010722^{* * *}$ & 0.002039 & -5.257321 & 0.0000 \\
\hline SOE & $0.017642^{* * *}$ & 0.005178 & 3.407005 & 0.0007 \\
\hline H10 & $3.39 \mathrm{E}-05$ & 0.000156 & 0.216936 & 0.8283 \\
\hline $\mathrm{R}^{2}$ & \multicolumn{5}{|c}{0.024} \\
\hline F value & \multicolumn{5}{|c}{$153^{* * *}$} & \\
\hline Sample size & \multicolumn{5}{|c}{} \\
\hline
\end{tabular}

Note: * means significant at the $10 \%$ level, $* *$ means significant at the $5 \%$ level, and *** means significant at the $1 \%$ level. 
Table 13. Return of office expenses

\begin{tabular}{c|c|c|c|c}
\hline Variable & Coefficient & Std. Error & t-Statistic & Prob. \\
\hline Intercept & $0.032862^{* * *}$ & 0.004561 & 7.204998 & 0.0000 \\
\hline IC & $-1.21 \mathrm{E}-05^{* * *}$ & $3.06 \mathrm{E}-06$ & -3.960965 & 0.0001 \\
\hline Size & $-0.000926^{* * *}$ & 0.000202 & -4.580587 & 0.0000 \\
\hline SOE & $-0.001747^{* * *}$ & 0.000503 & -3.473851 & 0.0005 \\
\hline H10 & $1.06 \mathrm{E}-05$ & $1.51 \mathrm{E}-05$ & 0.703798 & 0.4817 \\
\hline $\mathrm{R}^{2}$ & \multicolumn{5}{|c}{0.056} \\
\hline F value & $18.254^{* * *}$ \\
\hline Sample size & 1246 \\
\hline
\end{tabular}

Note: * means significant at the $10 \%$ level, $* *$ means significant at the $5 \%$ level, and $* * *$ means significant at the $1 \%$ level.

Table 13 is the regression results of the model based on the assumption of H3. From the table, we can see that in the multiple linear regression, the coefficient of internal control quality and (office expenses/total operating income) is negative, and the result is significant at the $1 \%$ level. In other words, the quality of internal control and the proportion of office expenses show the expected significant negative correlation, which shows that the quality of internal control has a significant negative impact on the proportion of office expenses.

Table 14. Return of travel expenses

\begin{tabular}{c|c|c|c|c}
\hline Variable & Coefficient & Std. Error & t-Statistic & Prob. \\
\hline Intercept & $0.024831^{* * *}$ & 0.002959 & 8.392277 & 0.0000 \\
\hline IC & $-6.08 \mathrm{E}-06^{* * *}$ & $1.93 \mathrm{E}-06$ & -3.149885 & 0.0017 \\
\hline Size & $-0.000786^{* * *}$ & 0.000130 & -6.064485 & 0.0000 \\
\hline SOE & $-0.000939^{* * *}$ & 0.000319 & -2.948451 & 0.0033 \\
\hline H10 & $-1.80 \mathrm{E}-06$ & $9.71 \mathrm{E}-06$ & -0.185267 & 0.8530 \\
\hline $\mathrm{R}^{2}$ & \multicolumn{5}{|c}{0.060} \\
\hline F value & \multicolumn{5}{|c}{$1247^{* * *}$} \\
\hline Sample size & \multicolumn{5}{|c}{} \\
\hline
\end{tabular}

Note: * means significant at the $10 \%$ level, ** means significant at the $5 \%$ level, and $* * *$ means significant at the $1 \%$ level.

Table 14 is the regression results of the model based on the assumption H4. From the table, we can see that in the multiple linear regression, the coefficient of internal control quality and (travel expenses/total operating income) is negative, and the results are significant at the $1 \%$ level. In other words, the quality of internal control and the proportion of travel expenses show an expected significant negative correlation, which shows that the improvement of the quality of internal control can effectively reduce the proportion of travel expenses in total operating income.

Table 15. Regression of R\&D Expenditure

\begin{tabular}{c|c|c|c|c}
\hline Variable & Coefficient & Std. Error & t-Statistic & Prob. \\
\hline Intercept & $0.234525^{* * *}$ & 0.028784 & 8.147773 & 0.0000 \\
\hline IC & $-2.19 \mathrm{E}-05$ & $1.98 \mathrm{E}-05$ & -1.103113 & 0.2702 \\
\hline Size & $-0.008719^{* * *}$ & 0.001255 & -6.949134 & 0.0000 \\
\hline SOE & 0.001387 & 0.003140 & 0.441637 & 0.6588 \\
\hline
\end{tabular}




\begin{tabular}{|c|c|c|c|c|}
\hline H10 & 0.000167 & $9.41 \mathrm{E}-05$ & 1.778836 & 0.0755 \\
\hline $\mathrm{R}^{2}$ & \multicolumn{4}{|c|}{0.041} \\
\hline F value & \multicolumn{4}{|c|}{$14.632^{* * *}$} \\
\hline Sample size & \multicolumn{4}{|c|}{1384} \\
\hline
\end{tabular}

Note: * means significant at the $10 \%$ level, ** means significant at the $5 \%$ level, and *** means significant at the $1 \%$ level.

Table 15 is the regression result of the model based on the assumption H5. From the table, we can see that in the multiple linear regression, the coefficient of internal control quality and (R\&D expenditure/total operating income) is negative, but the result is not significant. This means that although the quality of internal control is negatively correlated with the proportion of $\mathrm{R} \& \mathrm{D}$ expenditure, the improvement of internal control quality cannot effectively reduce the proportion of $\mathrm{R} \& \mathrm{D}$ expenditure in total operating income.

Table 16. Return of business entertainment

\begin{tabular}{c|c|c|c|c}
\hline Variable & Coefficient & Std. Error & t-Statistic & Prob. \\
\hline Intercept & $0.032286^{* * *}$ & 0.005653 & 5.711600 & 0.0000 \\
\hline IC & $-1.17 \mathrm{E}-05^{* * *}$ & $3.69 \mathrm{E}-06$ & -3.168225 & 0.0016 \\
\hline Size & $-0.001006^{* * *}$ & 0.000250 & -4.021975 & 0.0001 \\
\hline SOE & $-0.000988^{*}$ & 0.000616 & -1.603298 & 0.1091 \\
\hline H10 & $1.20 \mathrm{E}-05$ & $1.86 \mathrm{E}-05$ & 0.647535 & 0.5174 \\
\hline $\mathrm{R}^{2}$ & \multicolumn{5}{|c}{0.033} \\
\hline F value & $10.036^{* * *}$ \\
\hline Sample size & 1191 \\
\hline
\end{tabular}

Note: * means significant at the $10 \%$ level, $* *$ means significant at the $5 \%$ level, and $* * *$ means significant at the $1 \%$ level.

Table 16 is the regression result of the model based on the assumption H6. From the table, we can see that in the multiple linear regression, the coefficient of internal control quality and (business entertainment/total operating income) is negative, and the result is significant at the $1 \%$ level . In other words, the quality of internal control and the proportion of business entertainment expenses show an expected significant negative correlation, which shows that the improvement of the quality of internal control can effectively reduce the proportion of business entertainment expenses in total operating income.

Table 17. Return of agency fees

\begin{tabular}{c|c|c|c|c}
\hline Variable & Coefficient & Std. Error & t-Statistic & Prob. \\
\hline Intercept & $0.074324^{* * *}$ & 0.008328 & 8.924824 & 0.0000 \\
\hline IC & $-3.80 \mathrm{E}-05^{* * *}$ & $5.34 \mathrm{E}-06$ & -7.123481 & 0.0000 \\
\hline Size & $-0.001962^{* * *}$ & 0.000368 & -5.325102 & 0.0000 \\
\hline SOE & $-0.001451^{*}$ & 0.000911 & -1.593025 & 0.1114 \\
\hline H10 & $-4.97 \mathrm{E}-06$ & $2.74 \mathrm{E}-05$ & -0.181702 & 0.8558 \\
\hline$R^{2}$ & \multicolumn{5}{|c}{0.033} \\
\hline F value & \multicolumn{5}{|c}{1115} \\
\hline Sample size & \multicolumn{5}{|c}{$156^{* * *}$} \\
\hline
\end{tabular}


Note: * means significant at the $10 \%$ level, ** means significant at the $5 \%$ level, and $* * *$ means significant at the $1 \%$ level.

Table 17 is the regression results of the model based on the assumption H7. From the table, it can be seen that in the multiple linear regression, the coefficient of internal control quality and (intermediary fee/total operating income) is negative, and the result is obviously significant. In other words, the quality of internal control and the proportion of intermediary fees present an expected significant negative correlation, which shows that the improvement of the quality of internal control can effectively reduce the proportion of intermediary fees.

\section{Conclusion and Enlightenment}

This research takes 2016 listed manufacturing companies as the research object, and empirically examines the influence of internal control quality on the proportion of administrative expenses and the proportion of each component of administrative expenses. The study found that: (1) The improvement of internal control quality helps to significantly reduce the proportion of overall management costs. (2) Effective internal control can significantly suppress the proportion of employee compensation, office expenses, travel expenses, business entertainment expenses, and intermediary expenses in total operating income, and the improvement of the quality of internal control has a relatively weak inhibitory effect on the proportion of employee compensation. (3) The improvement of internal control quality cannot effectively suppress the proportion of $R \& D$ expenditure in operating income.

In the context of the comprehensive implementation of internal control by listed companies in my country, listed companies have stepped up their internal control construction. In order to better meet the needs of the development of corporate internal control, this study suggests that companies can focus on the compensation of employees, office expenses, travel expenses, business entertainment and agency fees when strengthening internal controls related to management expenses. Control, and the internal control requirements related to $R \& D$ expenditure can be slightly reduced. When it is difficult for an enterprise to achieve perfection, it should focus on strengthening internal control in order to better realize the goal of maximizing corporate profits and strengthen the competitiveness and vitality of the enterprise.

\section{References}

[1] Hou Baoliang. Analysis of common practices of foreign internal control [J]. Commercial Accounting, 2014 (23): 88-89.

[2] He Yu. Job fraud, internal control, and internal auditing_ Comments on the job fraud case of Societe Generale in France. [J]. Audit Research. 2009(02)

[3] Lu Rui, Liu Jianhua, Xu Ning. Internal control, property rights and executive compensation performance sensitivity [J]. Accounting Research, 2011 (10): 42-48+96.

[4] Chi Guohua, Guo Jingjing. Does the quality of internal control affect executive compensation?_— Based on the empirical evidence of Chinese A-share listed companies[J]. Journal of Nanjing Audit University, $2015,12(01)$

[5] Chen Donghua, Liang Shangkun, Jiang Dequan. The cost and choice of executive incentive contracts under different marketization processes: monetary compensation and on-the-job consumption [J]. Accounting Research, 2010 (11): 56-64, 97.

[6] Wan Hualin. A review of foreign on-the-job consumption research [J]. Foreign Economics and Management, 2007 (9): 39-41, 65.

[7] Dou Xiangsheng, Wang Zaifeng, Zhang Ruixiong. The influence of internal control on executive compensation and on-the-job consumption[J]. Business Research, 2017(05):109-113.

[8] Li Jingping, Xue Yiyi. Current local government public funds eating and drinking phenomenon and governance research [J]. Administration and Law, 2010 (6): 1-5. 
[9] Mou Shaohong, Li Qihang, Chen Hanwen. Internal control, nature of property rights and excess in-service consumption—_Based on the empirical research of non-financial listed companies from 2007 to 2014. [J]. Audit Research. 2016 (04)

[10] Fu Chao. Free cash flow, internal control and hidden corruption of executives-empirical evidence of stateowned listed companies under the background of eight regulations [D]. Tianjin University of Commerce, 2018.

[11] Lu Rui, Wei Minghai, Li Wenjing. Management power, on-the-job consumption and property rights efficiency: Evidence from listed companies in China [J]. Nankai Management Review, 2008(05): 85$92+112$.

[12] Li Wanfu, Lin Bin, Song Lu. The role of internal control in company investment: efficiency promotion or inhibition? [J]. Management World. 2011 (02)

[13] Wu Ning, Li Kao team, Li Guodong. Internal control, marketization process and enterprise risk-taking [J]. Business Research 2015 (07)

[14] Fang Hongxing, Chen Jiaojiao, Yu Qiaoye. Research on the Influencing Factors of Internal Control Audit Fees. [J]. Audit and Economic Research. 2016 (04)

[15] Quan Xiaofeng, Xu Xingmei. Venture Capital, Internal Control and Audit Pricing[J]. Financial Research, 2017 (6): 132 145.

[16] Song Yinghui, Chen Yanrong. The impact of the effectiveness of internal control on audit pricing based on the empirical verification of the Shenzhen Stock Exchange's manufacturing industry [J]. Taxation and Economy, 2013 (5): 53 59.

[17] Xiao Chengmin, Li Rong. Will internal control affect audit opinions? [J]. Accounting and Economics Research, 2012 (2) 34 41.

[18] Li Yuedong, Zhang Dong, Liu Weiwei. Major defects in internal control, nature of property rights and audit pricing. [J]. Audit Research. 2014 (02)

[19] Deng Wentao, Ping Aijia, Xiong Huanhuan. Research on the influence of internal control and management power on audit fees [J]. Chinese Certified Public Accountant, 2018 (05): 49-54+3.

[20] Zhou Meihua, Lin Bin, Lin Dongjie. Management power, internal control and corruption governance. [J]. Accounting Research. 2016(03)

[21] Lu Yuanyuan. Research on the impact of on-the-job consumption on corporate performance [D]. Capital University of Economics and Business, 2018. [22] Feng Mei,Li Chan,McVay S . Internal control and management guidance [J]. Journal of Accounting and Economics,2009,48: 190209 .

[22] Kanodia C, Lee D . Investment and disclosure: the disciplinary role of periodic performance reports [J]. Journal of Accounting Research,1998,36:3355

[23] HART O . Financial contracting [J]. Journal of Economic Literature,2001, 39(4) :1079 - 1100 .

[24] Robert Simons . Control in an age of empowerment. Harvard Business . 1995

[25] Gianmario Verona. A Resource-Based View of Product Development[J] . The Academy of Management Review . 1999 (1)

[26] Kaplan R, Norton D. The balanced scorecard: translating vision into action. IT Governance. Information Systems Control Journal,1996.

[27] K . Raghunandan,Dasaratha V . Rama . SOX Section 404 material weakness disclosures and audit fees [J]. Auditing,2006,(1): 99 - 114 .

[28] Hogan,Chris E . , Wilkins,Michael S . ,Evidence on the audit risk model: Do auditors increase audit fees in the presence of internal control deficiencies? [J]. Contemporary Accounting Research,2008,25( 1): $219-242$. 